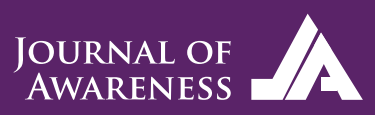

\%
Journal of Awareness

Volume / Cilt: 6, Issue / Sayl: 3, 2021, pp. 101-114

E-ISSN: 2149-6544

https://journals.gen.tr/joa

DOI: https://doi.org/10.26809/joa.6.3.02
Received / Geliș: 07.05.2021

Acccepted / Kabul: 03.07.2021

\title{
İngiltere emperyalizminin Osmanlı İmparatorluğu'ndaki yansıması: Baltalimanı Ticaret Anlaşması
}

\author{
Reflection of British imperialism in the Ottoman \\ Empire; Baltalimani Trade Agreement
}

Atilla Aydın (D)
Öğr.Gör., Gelişim Üniversitesi, MYO, Hava Lojistiği, TÜRKIYE, e- mail: ataydin@geşisim.edu.tr

Öz

Merkantilizm ile başlayan ve sanayi devrimiyle devam eden süreçte Avrupa devletleri önemli üretim artışları kaydetmiştir. Sanayi devrimini başlatan İngiltere, artan üretimini pazarlayabilmek ve ihtiyacı olan hammaddeleri alabilmek için diş pazarlara açılmıştır. Osmanlı İmparatorluğu pazarının İngiltere'ye mesafesinin kısa olması ve imparatorluğun yoğun nüfusu, İngiltere için cazip koşullar olarak öne çıkmıştır. Merkantilizm döneminde Osmanlı sermayesinin aşınmış olması ve kapitülasyon anlaşmaları nedeniyle ekonomik yapı güçsüz düşmüştür. Bu nedenle Osmanlı ekonomisi sanayi devrimine savunmasız yakalanmıştır. Siyasi koşulların da uygun hale gelmesiyle 1838 yılında İngiltere ile Osmanlı İmparatorluğu arasında Baltalimanı Ticaret Anlaşması imzalanmıştır. Bu çalışmanın amacı anlaşmaya giden sürecin mekanizmalarını ortaya koymak ve anlaşmanın sonuçlarını analiz etmektir. Anlaşmanın yürürlüğe girmesiyle Osmanlı yerli üretimi çökmüştür. Ayrıca Osmanlı ekonomisi dışa bağımlı bir hale gelmiş ve borç batağına girmiştir. Bu çerçevede anlaşmanın Avrupa finans kapitali açısından sonuçları da analiz edilmiştir. Anlaşmayla Osmanlı'nın değişen siyasal yapısının ortaya konması bu çalışmanın diğer bir çıktısını oluşturmuştur. Baltalimanı Ticaret Anlaşması'nın tarihsel süreç içinde neden ve sonuçlarının ortaya konmasıyla günümüzün küreselleşen ekonomik dünyasına ışık tutulması amaçlanmıştır.

Anahtar kelimeler: Merkantilizm, Sanayi Devrimi, Emperyalizm, İngiltere, Osmanlı İmparatorluğu

\section{Abstract}

In the process that started with mercantilism and continued with the industrial revolution, European states recorded significant production increases. Britain, which started the industrial revolution, opened up to foreign markets in order to market its increasing production and to buy the raw materials it needs. The short distance of the Ottoman Empire market to Britain and the dense population of the empire stand out as attractive conditions for England. During the mercantilism period, the Ottoman capital was eroded and the economic structure weakened due to the capitulation agreements. For this 
reason, the Ottoman economy was caught vulnerable to the industrial revolution. With the favorable political conditions, the Baltalimanı Trade Agreement was signed between Britain and the Ottoman Empire in 1838. The purpose of this study is to reveal the mechanisms of the process leading to the agreement and to analyze the results of the agreement. With the entry into force of the agreement, Ottoman domestic production collapsed. In addition, the Ottoman economy became dependent on foreign countries and fell into a debt trap. In this framework, the results of the agreement in terms of European financial capital were also analyzed. Another outcome of this study was to reveal the changing political structure of the Ottoman Empire with the agreement. It is aimed to shed light on today's globalizing economic world by revealing the causes and consequences of the Baltalimanı Trade Agreement in the historical process.

Keywords: Mercantilism, Industrial Revolution, Imperialism, England, Ottoman Empire

\section{GİRIŞ}

Osmanlı İmparatorluğu ekonomisi, sanayi devrimine kadar gücünü koruyabilmiş, ancak daha sonra giderek güçsüzleşerek çöküş sürecine girmiştir. Sanayi devrimi öncesinde Osmanlı ekonomisi, yönetici sinıf (askerler) ve üretici sınıf (reaya) olarak iki temel sınıftan oluşmaktadır. Reaya; köylüler, göçebeler, tüccarlar, zanaatkarlardan oluşmaktadır. Yönetici sınıfı ise merkezde yeniçeriler, taşrada sipahiler temsil etmektedir. Sipahilerin Avrupa'daki feodallerden farklı olarak özel toprak mülkiyeti bulunmamaktadır. Osmanlı toprak sisteminde toprak mülkiyeti devlete aittir. Bu durumda topraktan elde edilen gelirler de esasen devlete ait olmaktadır. Ancak devlet toprak gelirlerinden vergi toplama faaliyetlerini sipahilere vermekte, böylece sipahi ile reaya arasında bir iktisadi ilişki doğmaktadır. Sipahiler, vergi toplama işi karşılığında tımar adı verilen bir gelir elde etmekte, dolayısıyla reaya üzerinde yönetim ve yetki hakkına kavuşmaktadır. Bu sistemin en büyük avantajı, büyük bir harcama yapılmadan güçlü bir ordunun beslenebilmesini sağlamasıdır. Ayrıca taşradaki asayiş de bu sistem üzerinden sağlanabilmektedir (Kıray, 1995: 48). Sipahi ile reaya arasındaki sınıfsal çelişki, Avrupa'daki senyör ile serf arasındaki çelişkiye göre önemli farklılıklar göstermektedir. Öncelikle sipahi toprağın sahibi değildir, devletin temsilcisi konumunda bulunmaktadır. Oysa Avrupa'da senyör toprak sahibidir. Serf ise senyörün malı gibidir, hatta senyörlerin serfleri hukuken cezalandırma hakkı bulunmaktadır. Sipahilerin reaya üzerinde böyle bir hakkı söz konusu değildir. Ayrıca, sipahilerin elinden vergi toplama yetkisi alındığında kolaylıkla bir sınıfsal değişim yaşanabilmektedir. Bu nedenle Osmanlı'da sınıfsal çelişki Avrupa'da olduğu gibi derinleşmemiştir. Oysa batıdaki sınıfsal çelişki, gelişmenin dinamo- sunu oluşturmuş ve Fransız devriminin temellerini teşkil etmiştir. Osmanlı tımar sisteminde derin bir sınıfsal çelişkinin olmaması elbette sistemi kusursuz hale getirmemektedir. Hatta böyle bir ekonomik yapı, piyasa mekanizmasında meydana gelen olumsuzluklardan daha kolay etkilenmektedir. Bu nedenle dış ticaret kapitülasyonları ile Osmanlı ekonomisinin geniş ölçüde dünya piyasa ve para dalgalanmalarına henüz bağlanmamış olduğu dönemde dahi Kanuni zamanındaki büyük piyasa gelişiminin etkileri altında tımar sistemi çoktan bunalım geçirmeye başlamıştır (Berkes, 2013:275). Timar sistemindeki bozulmanin en önemli nedeni, sipahilerde ortaya çıkan feodalleşme arzusudur. Bu durum, sipahilerin merkezi otorite ile arasının bozulmasına yol açmış ve birçok bölgede isyanlar başlamıştır. Reaya da bu isyanlara katılmış, böylece taşrada huzursuzluk egemen olmuştur. İsyanların en bilineni Celali İsyanları olup, Kanuni Sultan Süleyman'ın padişahlığının son dönemlerine denk gelmiştir. İsyanların temelinde sipahilerin elinden vergi toplama yetkisinin alınması girişimlerinin yattığı bilinmektedir (Gökbunar, 2007: 13).

Tımar sisteminin tasfiyesinin ardından iltizam sistemi uygulanmaya başlanmıştır. İltizam sistemi, toprağın belirli bir ücret karşılığı belli yıllarla özel kişilere kiralanmasını ifade etmektedir (Yardımcı vd, 2020:63). İltizamları alan kişiler ise mültezim olarak adlandırılmaktadır. İltizam sisteminin en önemli özelliği, mültezimlere yereldeki hükümet sorumluluklarının da devredilmesi olmuştur (Tabakoğlu, 2016:332). Tımar sisteminin terkedilip iltizam sistemine geçilmesiyle birlikte kuvvetli bir ayan hiyerarşisi ortaya çıkmıştır (Kıray, 1995: 60). İlk ortaya çıtığında iltizam süresi üç yıl olarak belirlenmiş, ancak devletin finansman ihtiyacı artınca süre bir yıla kadar indirilmiştir. $\mathrm{Bu}$ durum nedeniyle vergi gelirleri tahribata uğramış 
ve malikane sistemi olarak adlandırılan yeni bir sisteme geçilmiştir. 1695 yılında uygulanmaya başlanan malikane sisteminde devlet, bir gelir kaynağından vergi toplama hakkını, vergiyi toplayacak kişiye hayatının sonuna kadar satmaktadır (Özvar, 2003:20). Malikane sisteminin uygulanmasıyla ayan sınıfı daha da zenginleşmiştir. Malikane sistemiyle ilk defa Osmanlı devleti servetini bir başka sınıfla paylaşmıştır, Ayanlar, hem vergi toplama görevini üstlenmiş hem de kredi verme mekanizması olmuşlardır. Bu iki yönüyle ayan sınıfı kısa sürede iktisadi bir güç haline gelmiş ve devlet tarafından bir rakip olarak görülmeye başlanmıştır. Osmanlı devleti, merkezi otoriteyi yeniden sağlayabilmek için çabalamaya başlamış ve bu çerçevede Üçüncü Selim döneminde Nizam-ı Cedit adıyla yeni ve modern bir ordu kurulmuştur. Ancak Rumeli ayanlarının isyanı ile bu yeni ordu dağıtılmış ve Üçüncü Selim tahttan indirilmiştir. Üçüncü Selim'den sonra tahta çıkan İkinci Mahmut ayanlarla bir anlaşma imzalamış ve böylece bir süre sessizlik sağlanabilmiştir. Keyder (2008)' e göre bu anlaşmanın imzalanmasının ardından merkezi otorite, ayanı siyasi düzeyde olduğu gibi iktisadi düzeyde de büyük ölçüde yenilgiye uğratmayı başarmıştır. Nitekim bu dönemde ayan sınıfının önce etkinliği azaltılmış, daha sonra tümüyle ortadan kaldırılabilmiştir.

Osmanlı ekonomisinin iç dinamikleri tarihsel süreç içerisinde bu dönüşümlere uğrarken ekonominin diş dünyasında da önemli gelişmeler yaşanmıştır. Avrupa merkantilizmiyle başlayan ve sanayi devrimiyle devam eden süreç, Avrupa devletlerinin kalkınmasını sağlamış, tarihte görülmemiş bir iktisadi dönüşüm ortaya çıkmıştır. Sanayi devrimi karşısında Osman11 İmparatorluğu bir gerileme sürecine girmiş ve ilerleyen süreçte açık pazar haline gelmiştir. Yeni pazar arayışlarına giren İngiltere ve diğer Avrupa devletleri ile Osmanlı arasındaki iktisadi ilişkiler giderek daha eşitsiz hale gelmiş ve bu süreç 1838 Baltalimanı Ticaret Anlaşması'na kadar devam etmiştir. Bu çalışmanın amacı, Baltalimanı Ticaret Anlaşması'nı tüm yönleriyle tartışmak ve anlaşmanın sebep ve sonuçlarını ortaya koymaktır. Çalışmanın girişten sonraki ikinci bölümünde Baltalimanı Ticaret Anlaşması'nın imzalanması sonucunu doğuran içsel ve dişsal etkenler analiz edilmiştir. Üçüncü bölümde anlaşma ve anlaşmanın hükümleri açılanmıştır. Dördüncü bölümde anlaşmanın Osmanlı imalat sanayii üzerindeki etkileri üzerinde durulmuştur. Beşinci bölümde ise anlaşmanın imalat sanayii dışındaki etkilerine, Avru- pa finans kapitalinin Osmanlı finans piyasası üzerindeki egemenliği ele geçirme süreci incelenmiştir. Son bölüm sonuç kısmına ayrılmıştır.

\section{BALTALIMMANI TICARET ANLAŞMASI ÖNCESİ SÜRECINN ANALİİ}

Baltalimanı Ticaret Anlaşması öncesinde yaşanan iktisadi ve siyasi gelişmeler, sürecin doğru anlaşılması açısından önem arz etmektedir. Osmanlı maliyesi yukarıda açıklandığı gibi zaten bunalım geçirmektedir. Bunalımın derinleşmesi başta Avrupa coğrafyasında yaşanan iktisadi ve sosyal dönüşümler ile gerçekleşmiştir. Ayrıca Osmanlı İmparatorluğu içinde yaşanan siyasal gelişmeler de bu süreçte incelenmesi gereken etkenler arasında bulunmaktadır.

\subsection{Merkantilizm ve Osmanlı İmparatorluğu}

15. Yüzyıldan başlayarak 18. Yüzyıl ortalarına kadar gücünü ve politikasını sürdüren merkantilizm, bireyin refahını yükseltmeyi amaç edinen modern ekonomi teorisinden farklı olarak devletin egemenliğini ve zenginleşmesini amaç edinmiştir. Bireylerin zenginliğinin ancak devletin zenginleşmesi ile gerçekleşeceği inancı, bu akımın temel prensibini oluşturmaktadır (Kazgan, 1982: 6). Merkantilizmin ilk amacl, devletin değerli maden biriktirmesi ve bu madenleri elinde tutmasıdır (Aydın, 2021: 33). Ayrıca merkantilizm, ulusal bir sanayi oluşturmayı hedeflemektedir. Bu çerçevede korumacı gümrük politikaları uygulayan devletler, yerli üretimi özendirebilmek için tüm iktisadi araçları kullanmışlardır (Hafter, 1964: 7,8).

Merkantilizm, tüm Avrupa devletlerinde homojen ekonomi politikalarını ifade etmemektedir. Örneğin İspanya, Peru ve Antillerden sağladığı altınlarla kısa zamanda Avrupa'nın en çok altına sahip olan ülkesi haline gelmiştir. Ancak böyle bir zenginleşme modeli, altın bolluğu nedeniyle fiyat düzeyinin artmas1na neden olmuştur. Çalışmadan yaşamını sürdüren zenginler ülkesi haline gelen İspanya, kısa zamanda ticaret ve sanayideki üstünlüğünü İngiltere ve Fransa'ya kaptırmıştır. İspanya'da iktisat politikalarının tek yönlü olarak basılmış ve külçe altın stokunu arttırmayı amaçlaması, bu ülkeyi altın ihraç eden bir ülke haline getirmiştir. Nitekim 18. Yüzyılın sonunda İspanya, İngiltere ve Fransa ile karşılaştırıldığında az gelişmiş bir ülke konumuna düşmüştür (Kazgan, 1982: 14). Fransa'da merkantilizm, değerli maden 
stoklarını dış ticaret yoluyla arttırmayı amaçlamıştır. Dış ticaretin attırılmasının ilk koşulu olarak ise sanayileşme politikası olarak görülmüştür. Sanayi mallarının yurtdışı pazarlara ihraç edilerek dış ticaret fazlası verilmesi ve bu yolla değerli maden stokunun arttırılması birinci araç olarak görülmüştür. Fransa'da merkantilizmin ideologluğunu yapan Colbert ayn zamanda devlet adamıdır. Colbert, Fransız mallarını bütün dünyada pazarlamak ve hammaddeleri diş ülkelerden sağlamak için büyük sermayeli kuruluşların gerektiği düşüncesinden hareket ederek Indes Crianteles ve Indes Cocidentales adlı iki büyük şirket kurdurmuştur. Anonim şirket türünün ilk denemeleri olan bu şirketlere halkın ortak olması sağlanmıştır. $\mathrm{Bu}$ özellikleri itibariyle Fransız merkantilizmine sanayi merkantilizmi de denmektedir (Güneş, 2006: 147). İngiltere ise merkantilizmin değerli maden stokunu arttırma politikasında ticareti en önemli araç olarak görmüştür. İngiltere de tıpkı Fransa gibi dış ticaret fazlası sağlayacak korumacı iktisat politikalarına başvurmuştur. Korumacılığın katı bir iktisat politikası olarak kullanılmasının kökeni merkantilizme dayanmaktadır (Roberts, 2013: 13). Daha önceki dönemlerde de gümrük politikaları uygulanmakla birlikte bunun bir iktisat ve dış ticaret politikası olarak kullanılması merkantilizm ile olmuştur. Merkantilizm, bu yapısıyla Avrupa coğrafyasında 1450 ile 1750 yılları arasında 300 yıl hüküm sürmüştür. (Demir ve Kurt, 2020: 382). 18. Yüzylldan itibaren ise Avrupa'da merkantilizme ve ticari kapitalizme bir tepki olarak fizyokrasi akımı ortaya çıkmıştır (Kazgan, 1993: 40). 18. Yüzyılın ikinci yarısında Fransa kralı 15. Louis'nin doktoru olan Quesnay Yeni Doğal Düzen adlı çalışmasında doğanın ve toprağın hareket noktasını meydana getiren bir ekonomik dolaşım sistemi önermiştir. Bu şekilde temelleri atılan fizyorasi akımı, merkantilizm nedeniyle zarar gören tarımı önceleyen bir sistem önermiştir. Merkantilist politikalar nedeniyle köylüler fakirleşmiş, tarımsal alanlardaki nüfus kentlere göç etmiştir. Köylülerin fakirleşmesi nedeniyle sanayi mallarına olan talep azalmış, kentlerdeki gelir azlığı nedeniyle de talep açı̆̆ı kapatılamamıştır. Buna bir çözüm olarak değerli maden biriktirmeyi esas alan merkantilizm yerine tarımsal ücretleri ve bu yolla ekonomik refahı arttırmayı hedefleyen fizyokrasi hareketinin temelleri oluşmaya başlamıştır (Kazgan, 1982: 20). Fizyokratlara göre iktisadi hayatta doğal bir düzen vardır ve bu doğal düzen en akılcı düzendir (Karakayalı ve Dilber, 2010: 50). Bu düşünceden hareketle fizyokrasi, korumacılığa bir tepki olarak liberal an- layışı temsil etmektedir.

Osmanlı İmparatorluğu'nun merkantilizm ile ilk tanışmasının Fransa ile imzalanan kapitülasyon anlaşması olduğu bilinmektedir. 1535 yılında Kanuni Sultan Süleyman ile Fransa kralı Birinci Francois arasında imzalanan ve Osmanlı tarihine ilk kapitülasyon olarak geçen anlaşma, esasen siyasal yönden Osmanlı devletinin isteklerine uygun bir sonuç yaratmaya yönelmiştir. Fakat iktisadi yönden bakıldığında Fransa lehine sonuçlar verdiği görülmektedir. Kanuni Sultan Süleyman Avrupa'yı istila etme planında en büyük engel olarak İspanya kralı Şarlken'i görmektedir ve bu nedenle Avrupa'da kendisine bir müttefik aramaktadır. Kanuni Sultan Süleyman, ilk olarak Papa'nın nüfuzunu kullanan Medici ailesine başvurmuş, ancak Medici'ler kendilerini Şarlken karşısında güçsüz gördüklerinden ve İslam dünyası ile ittifak yapmak istememelerinden ötürü bu ittifaka yanaşmamışlardır (Kazgan, 1982: 27-28). Fransa kralı Birinci Francois ise Şarlken ile girdiği güç mücadelesinde geride kalmış, hatta Şarlken'e esir düşmüştür. Birinci Francois kendisine yardım edecek tek güç olarak Osmanlı İmparatorluğu'nu görmektedir (Jagic, 2010: 3). Böylece gerek Kanuni Sultan Süleyman'ın ittifak arayışı içinde olması gerekse Birinci Francois'nın Şarlken karşısında Osmanlı'ya ihtiyaç duyması nedeniyle kapitülasyonların iktisadi ve siyasi temelleri atılmıştır. Anlaşmanın temeli Kanuni'nin Fransa'nın güney limanlarına 200 parçadan oluşan savaş gemisi filosu göndermesi ve böylece Fransa'yı İspanya karşısında güçlendirmeye dayanmaktadır. Fransa'ya yapılan bu askeri yardımın Osmanlı'ya getireceği ekonomik yükün hafifletilmesi için yardımın bir kısmı krediye dönüştürülmüş ve bu borcun ödenebilmesi için Fransa'ya Akdeniz limanları arasında Osmanlı desteği ile serbest ticaret yapma olanağı verilmiştir. Fransa'nın Akdeniz ticaretini bu şekilde ele geçirmesiyle birlikte esasen Osmanlı pazarları üzerinde egemen olmasının de önü açılmıştır. Merkantilizm dönemi boyunca sanayisini önemli ölçüde geliştiren Fransa'nın böylesine geniş bir pazarı değerlendirme isteği de kapitülasyonlar üzerinden gerçekleşmiştir. Osmanlı İmparatorluğu daha önce de Venedik, Ceneviz gibi başka Avrupa milletlerine ticari imtiyazlar vermiştir. Ancak 1535 y1lında Fransa'ya verilen imtiyazlar, daha kapsamlı olması ve ilerleyen yıllarda diğer Avrupa ülkeleri ile imzalanacak olan ticaret anlaşmalarının altyapısını oluşturması açısından önem arz etmektedir (Acartürk ve Kılıç, 2021: 6). 
$\mathrm{Bu}$ devirde esasen Osmanlı İmparatorluğu'nun Avrupa devletlerine göre güçlü bir ekonomik yapısı bulunmaktadır (İnalcık, 2000: 248). Bu çerçeveden bakıldığında kapitülasyonların askeri yardım anlaşmasından daha ötesini ifade ettiği anlaşılmaktadır. Osmanlı İmparatorluğu, güçlü iktisadi yapısıyla merkantilizm sürecini yaşayan Avrupa için önemli pazar fırsatlarını barındırmaktadır. Nitekim Fransa, ilk kapitülasyonlarla sadece Osmanlı'ya olan borçlarını ödemekle kalmamış, Akdeniz ticaretinin tekelini ele geçirmiş ve Osmanlı'yı kendi ürettiği ürünlerin pazarı haline getirmiştir. Buna benzer anlaşmalar daha sonra diğer Avrupa devletleri ile de imzalanmış ve Osmanlı İmparatorluğu, Avrupa devletleri için tamamen açı pazar haline gelmiştir. Hatta Avrupa coğrafyasında merkantilist politikaların yaşaması adeta Osmanlı'dan koparılacak tavizlere bağlı hale gelmiştir (Kazgan, 1982: 33). Osmanlı İmparatorluğu'nun bu yıllarda ticaret ilişkisine en yoğun olarak girdiği devletler; Fransa, İngiltere ve Hollanda olmuştur. Ancak 17. Yüzyıl itibariyle Hollanda, gemi tasarım tekniği ve ticaretteki üstünlügü nedeniyle en büyük paya sahip hale gelmiştir (Wallerstein, 2005: 66). 1650'li yıllardan itibaren ise İngiltere, Hollanda'yı geriletmeyi başarmış ve Akdeniz ticaretinde üstünlüğünü hissettirmiştir (Pamuk, 2015: 138). Avrupa ülkelerinin aralarında rekabet konusu haline gelen Osmanlı ekonomik yapısı gerilemeye başlamış, imparatorluk yeni topraklar da ele geçiremeyince ve mevcut toprakları değerlendirme yolundaki çabalar kapitülasyonlar nedeniyle uygulanamayınca çöküş süreci başlamıştır. Ayrıca fakirleşmekte olan kapıkulları ve halk da batı mallarını alamaz hale gelmiş, 18. Yüzyıl itibariyle merkantilizm de Osmanlı İmparatorluğu'nda aradığını bulamaz hale gelmiştir. Bu durum Şark Meselesi olarak adlandırılan sorunun temelini oluşturmaktadır. Bir başka ifadeyle Şark Meselesi, aslında bir doğu sorunu değil Avrupa sorunudur ve Avrupa siyasi güç dengeleri nedeniyle ortaya çıkmıştır. Batılı devletlere göre imparatorluk ya eski güçlü günlerine dönmeli veya parçalanıp paylaşılmalıdır. Bu konuda Avrupa ülkeleri anlaşamamış ve bu nedenle zaman zaman Osmanlı'nın varlığının korunmasından yana olmuşlardır (Yalçın, 2015: 81). Bir başka ifadeyle Osmanlı'yı aralarında paylaşamayan Avrupa devletleri imparatorluğu ayakta tutmaktadır. Fransa önceleri Osmanlı üzerindeki baskıyı arttırmış, hatta bir savaşı dahi göze almıştır. Ancak böyle bir savaş karşısında İngiltere'nin tutumu kestirilemediğinden Colbert savaştan vazgeçmiş ve bu süreç 1671 kapitülasyonları ile sonuçlanmıştır. 1671 ka- pitülasyonları 1535 kapitülasyonlarından farklı olarak Fransa'nın askeri üstünlüğüne vurgu yapmaktadır. Yeni anlaşmaya göre gümrük vergileri $\% 5^{\prime}$ ten $\% 3^{\prime} \mathrm{e}$ indirilmiştir. Ayrıca Hindistan ve Uzak Doğu'dan gelen Fransız malları Kızıldeniz ve Misır'dan serbestçe geçebilecektir. Böylece Hint ve Çin ipeklileri ile İran halı ve kumaşları, bütün ihraç ve transit gümrüklerinden muaf tutulmuş ve bu malların ticareti Fransa'nın tekeline verilmiştir. Gümrük vergileri, Osmanlı İmparatorluğu'nun kervan yollarındaki ticaret ve yerleşim merkezlerinin önemli bir gelir kalemini oluşturduğundan bu gelirlerin aşınması kısa sürede bu bölgelerin iktisadi çöküşüne neden olmuştur (Kazgan, 1982: 35).

Osmanlı İmparatorluğu bu dönemde başka Avrupa devletlerine de benzer ayrıcalıklar vermiştir. İngiltere'ye ilk kapitülasyon 1580 yılında verilmiş ve bu hakların kapsamı ilerleyen yıllarda genişletilmiştir. Hollanda'ya da ilk kapitülasyon 1612 y1lında verilmiştir. Pasarofça Antlaşması ile Avusturya'ya 1718 yılında, Sicilya Krallığı'na 1740 yılında, Prusya'ya 1761 yılında, İspanya'ya 1783 yılında benzer imtiyazlar verilmiştir (Pamir, 2002, 89). Böylece merkantilizm karşısında Osmanlı İmparatorluğu iktisadi açıdan savunmasız kalmış ve tam bir açık pazar haline gelmiştir. Buna karşılık Rusya, merkantilizmin nimetlerinden faydalanamadığı için Osmanlı topraklarına göz dikmiş ve çıkarlarını savaş yoluyla sağlamlaştırma yolunu seçmiştir. Avrupa ülkeleri ise sözü edilen Şark Meselesi konusunda Osmanlı İmparatorluğu'nun devamı yönünde bir tutum sergilemiştir.

Her ne kadar kapitülasyonlar ile Osmanlı Devleti Avrupa ülkeleri karşısında güç kaybetmişse de 18. Yüzyıl başında hala Uzak Doğu, Yakın Doğu ve Afrika ticaret yollarını elinde tutmaktadır. Ayrıca Avrupa ülkelerine olan ihracat azalmış olsa da devam etmektedir. İhracata konu olan mallar; buğday, hububat çeşitleri, pamuk, ham ipek, deri gibi ürünlerdir (Pamuk, 2015: 163). Kapitülasyonlardan en fazla yararlanan Fransa, Osmanlı'ya sadece bazı önemli metaller, kumaş, tuz ve şeker satmaktadır. İngiltere'ye de ihracat devam etmekte, Osmanlı Sanayii tüm olumsuzluklara rağmen üretim yapabilecek gücünü korumaktadır. Ayrıca Ege'deki adalardan zeytinyağı, yün, ipek, şarap, balmumu, peynir, zımpara gibi ürünler de Avrupa devletlerine ihraç edilmektedir (Aygün, 2017: 9). Üretim ve ihracat olumsuzluklara rağmen devam ettiği halde ticaret hadlerinde Osmanlı aleyhine önem- 
li değişiklikler yaşanmıştır. Fransa ipekli ve yünlü kumaşların, İngiltere metal eşya ve gemi aksamlarının fiyatlarını sürekli arttırırken Osmanlı'nın ihraç ettiği malların fiyatları sürekli olarak düşmüştür. Bunun en önemli nedeni, İngiltere ve Fransa'nın sömürgelerinde Osmanlı'nın ihraç ettiği malların aynılarının daha ucuza satılmasıdır. Osmanlı üreticileri rekabet edebilmek adına ihraç mallarının fiyatlarını sürekli olarak düşürmeye razı olmuştur. Ticaret hadlerindeki bu olumsuz değişim, Osmanlı'nın sermaye birikimini engellemiş ve merkantilizmin devamı olan sanayi devrimi sürecine çok güçsüz girmesi sonucunu doğurmuştur. 1740 yılında imzalanan son kapitülasyon anlaşmasını öncekilerden ayıran en önemli özelliği sürekli olmasıdır (Pamir, 2002: 89). 1740 kapitülasyonlarından itibaren Osmanlı son gücünü de kaybetmiş ve 1760 yılından itibaren Avrupa'nın gireceği sanayi devrimi sürecine dahil olamamıştır.

Merkantilizm dönemi boyunca Osmanlı İmparatorluğu sürekli olarak güç kaybetmiş, ancak dönemin sonuna kadar direnmeyi başarmıştır. Avrupa ülkeleri ile imzalanan tüm ticaret anlaşmaları Osmanlı'nın aleyhine sonuçlar doğurmuştur. Merkantilizmin sonuna gelirken sermaye birikimi hiç kalmayan Osmanlı'nın çöküş süreci hızlanmıştır. Nitekim Avrupa mallarının Doğu Akdeniz pazarlarını istila etmesi sanayi devriminden sonra gerçekleşmiştir (Pamuk, 2009: 139).

\subsection{Sanayi Devrimi ve Osmanlı İmparatorluğu}

Son kapitülasyon anlaşmasının imzalanmasının ardından Avrupa ekonomisi yeni bir sürece girmiş, merkantilizm ile sağlanan sermaye birikimi ve teknik buluşlar, sanayi devriminin temelini oluşturmuştur. Teknik gelişmenin üç büyük sektörde etkili olduğu görülmektedir. Öncelikle sanayide yeni makineler icat edilmiştir. Özellikle matbaacılıkta kullanılan yeni tip makinelerin bulunması, giyim ve ayakkabı imalatında kullanılan dikiş makinesinin icadı, inşaat alanında demir, metal iskele ve kiriş kullanılması, makine yapımının mekanik yöntemlerle gerçekleşmesi sanayi devrimi sürecinde görülen başlica yeniliklerdir. Devrim sayılacak buluş ise seri üretime geçiși sağlayan buhar makinesinin James Watt tarafından geliştirilmesi olmuştur. Tarım alanında; toprağın ekilmesinde eski tohum atma yönteminin bırakılması, hayvanların rasyonel beslenmesi, nadasin terkedilmesi, kimyasal gübrenin kullanılmasıyla birlikte birim alan üzerinde verimliliğin yükselmesi, tarımsal üretimde kullanılan yeni makinelerin icadı başlıca yeniklerdir. Tarım ve sanayinin dışında üçüncü büyük dönüşüm ise ulaştırma sektöründe gerçekleşmiştir. Buhardan sadece sanayi alanında faydalanılmamış, metalürji alanında kaydedilen yeniliklerden de yararlanılarak ulaştırma alanında iki büyük yenilik kaydedilmiştir. Bunlardan ilki demiryollarının yapılmasıdır. İkinci büyük ilerleme denizcilik alanında yaşanmış, yelkenin yerini buhar gücü almış, ayrıca gemi yapımında ağaç yerine demir kullanılmaya başlanmıştır (Maillet, 1983: 44).

Sanayi devrimi ile birlikte büyük üretim artışları sağlanmıştır. Örneğin dokuma için ithal edilen ham pamuk miktarı 1701 yılında bir milyon libre, 1750'de 3 milyon libre, 1781 yılında ise 5 milyon libre olmuştur. 1802 yılına gelindiğinde ise bu miktar 60 milyon libreye kadar çıkmıştır. Teknolojik üretimin görüldüğü her alanda durum benzer şekilde ilerlemiştir. Kırk yılda kömür üretimi on kat artmış, demir üretimi ise 1788 yılında 68.000 tondan 1839 yılında 1.347 .000 tona çıkmıştır (Kazgan,1982:45).

Sanayi devriminin merkezi İngiltere olarak kabul edilmektedir. Sanayi devrimiyle İngiltere önemli bir ekonomik güce ulaşmış, dünyanın en büyük üreticisi ve ihracatçısı konumuna geçmiştir (Hobsbawn, 1987: 1). İngiltere'de sanayi devriminin ilk yıllarında özellikle pamuklu sanayiinde büyük ilerlemeler kaydedilmiştir. 1820 yılında İngiltere'de pamuklu sanayi sektörü üretiminin \%60'ının ihraç edildiği bilinmektedir (Freeman ve Soete, 2003: 43). İngiltere'nin bu süreçte karşılaştığı en büyük engel, diğer Avrupa devletleri olmuştur. İngiltere dışındaki Avrupa ülkeleri de kendi sanayi devrimlerini gerçekleştirmek üzere müdahaleci ve korumacı politikalara başvurmakta, böylece İngiltere'nin pazar olanakları kısıtlanmaktadır (Yerasimos, 1977: 547). Sanayi devrimiyle üretim düzeyi büyük artış gösteren İngiltere, mallarını satabilmek için Latin Amerika, Çin ve Osmanlı pazarlarına açılmış ve bu bölgelerdeki ülkelerle bazen yerel iktidarlarla anlaşarak bazen de zorla serbest ticaret anlaşmaları imzalamıştır (Kütükoğlu, 1974: 74). Osmanlı İmparatorluğu ile imzalanan 1838 Baltalimanı Ticaret Anlaşması'nın temelinde bu anlayış yatmaktadır. Ayrıca İngiltere sanayisinin ihtiyacı olan pamuk, yün, tiftik, maden gibi ürünlerde Osmanlı İmparatorluğu zengin kaynaklara sahiptir. Osmanlı nüfusunun büyüklüğü de İngiltere için büyük bir pazarı ifade etmektedir. İngiltere'nin Osmanlı pazarını istemesindeki diğer bir önemli faktör ise ulaştırma kolaylığıdır. İki devlet ar- 
ası mesafenin az olması ve İstanbul, Trabzon, Samsun, Selanik gibi büyük ticaret merkezlerine denizyolu ile ulaşabilme olanağı Osmanlı pazarının önemini arttıran önemli etkenler olarak görülmektedir (Yıldırım, 2001: 317).

İngiltere, Osmanlı pazarını ele geçirme hedefi karşısında Osmanlı'da uygulanan bazı iktisadi politikaları engel olarak görmektedir. İmparatorluk içindeki tekeller nedeniyle İngiltere ihtiyaç duyduğu bazı ürünleri, özellikle hammaddeleri istediği fiyattan alamamaktadır. Bazı ürünlere getirilen ihracat yasakları da bu ürünlerin yurtdışına çıkarılmasında sorunlar yaratmaktadır. İngiltere'nin en fazla şikayet ettiği politika ise yed-i vahit, yani tekel uygulamasıdır (Dura ve Altıparmak, 2000: 19). İngiltere, Osmanlı İmparatorluğu ile yapacağı bir serbest ticaret anlaşması ile bu engelleri de ortadan kaldırmayı amaçlamıştır.

1838 Baltalimanı Ticaret Anlaşması'na giden süreçte Osmanlı İmparatorluğu bu taleplere razı olmak zorunda kalmıştır. Merkantilizm ile başlayan iktisadi gelişme sürecine giremeyen Osmanlı ekonomisi, merkantilizm boyunca kapitülasyon anlaşmaları ve verilen tavizler nedeniyle kırılgan hale gelmiş ve giderek Avrupa'ya bağımlı bir yapıya bürünmüştür. Dış ticaret her ne kadar devam etse de hammadde ihraç edip bitmiş mamul ithal eden ekonomik yapı nedeniyle sermaye birikimi sağlanamamıştır. Avrupa ülkeleri ise bu dönemde üretimde ve ihracatta önemli ilerlemeler kaydederek sermaye birikimini hızla arttırmıştır. Sermaye birikimi, öncelikle İngiltere'de teknik gelişmelerle birleşince sanayi devrimi sürecini başlatmış ve üretim hacmini hızla arttırmıştır. Ayrıca ticaret hadlerinin İngiltere lehine değişmesi, diğer bir olumsuz gelişme olmuştur. Osmanlı İmparatorluğu, yetersiz sermaye birikimi ve mevcut kapitülasyon anlaşmaları nedeniyle sanayi devrimi sürecine girememiş ve kısa sürede İngiltere ekonomisinin açı pazarı haline gelmiştir. Bir başka ifadeyle Osmanlı İmparatorluğu ekonomisi sanayi devrimine savunmasız yakalanmıştır. Sanayi devrimi sonrasında Osmanlı sanayisi, elinde kalan son olanaklarını da kaybetmiş ve iktisaden çökmüştür. Buna rağmen İngiltere, bu gelişmeleri yeterli görmeyerek Osmanlı sanayi ve ticaret politikalarında kendisine engel gördüğü uygulamaları kaldırabilmek için çabalamaya başlamış ve bir serbest ticaret anlaşması yapabilmek için Osmanlı üzerindeki baskılarını arttırmıştır.

\subsection{Siyasi Nedenler}

İktisadi alanda yaşanan sorunların yanında siyasi alanda ortaya çıkan kargaşalar da Osmanlı İmparatorluğu'nu zayıflatmaktadır. 1838 Baltalimanı Ticaret Anlaşması'nın imzalanmasında etken olan önemli nedenlerden birinin Osmanlı merkezi yönetimiyle Mısır valisi Mehmet Ali Paşa arasındaki güç ve iktidar mücadelesi olduğu bilinmektedir (Timur, 1985: 23). Mısır'da gücünü arttırmak isteyen Mehmet Ali Paşa, imparatorluğun sınırlarını Arabistan'a kadar genişletmiş ve güçlü bir ekonomik yapı inşa etmiştir. Ancak Mehmet Ali Paşa'nın asıl hedefi Osmanlı'yı güçlendirmek değil, bölgede bağımsız bir imparatorluk kurmaktır (Tekeli ve İlkin, 1999: 53). Kısa süre içinde bölgede uygulanan iktisadi politikalar nedeniyle Mısır, Osmanlı İmparatorluğu'nun diğer bölgelerinin aksine gelişme sürecine girmiştir. Devletin ekonomideki ağırlığı arttırılmış, ayrıca dış ticaret devletleştirilmiştir (Clark, 2006: 507). Mehmet Ali Paşa'nın uyguladığı bir diğer politika ise İngiltere'nin rahatsız olduğu tekel sistemini yaygınlaştırmak olmuştur. Kapitülasyonlar yoluyla verilen imtiyazların kısıtlanması da Avrupa ülkelerini rahatsız etmeye başlamıştır (Puryear, 1969: 114). Osmanlı İmparatorluğu merkezi yönetimi bu sırada güçsüz düştüğünden birçok sorunla uğraşmaktadır. Yunanistan isyanını bastıramayan Osmanlı, Mehmet Ali Paşa'dan yardım istemek zorunda kalmıştır (Eşiyok, 2010: 75). Yardımı kabul eden Mehmet Ali Paşa isyanı başarıyla bastırmıştır, ancak kendisine vaat edilen Suriye ve Girit valilikleri verilmemiştir. Bunun üzerine Mehmet Ali Paşa bu vilayetleri işgal etmeye kalkmış ve Konya'ya kadar ilerleyerek sadrazam Reşit Mehmet Paşa'yı esir almıştır. İstanbul'a yaklaşmakta olan Mısır kuvvetlerini durdurabilmek için padişah İkinci Mahmut Rusya'dan yardım istemiştir. Bunun üzerine üç tane Rus savaş gemisi Haliç önlerine konuşlanmış ve Rusya ile Hünkar İskelesi Anlaşması imzalanmıştır (Ortaylı, 2005: 55). Anlaşma, bir dış saldırı olması durumunda askeri yardımı içermektedir. Buna karşılık boğazlardan yabancı gemilerin geçişi Rusya lehine kısıtlanmıştır (Eşiyok, 2010: 76). Rusya'nın emperyalist bir güç olarak bu şekilde ortaya çıkması ve boğazlarda egemenlik kurma çabası, İngiltere'yi doğal olarak rahatsız etmiştir. Osmanlı pazarını tamamen ele geçirmek isteyen İngiltere, bu anlayışla hemen harekete geçerek Mısır tehlikesi karşısında Osmanlı İmparatorluğu'na yardım teklifinde bulunmuştur. İngiltere, Osmanlı İmparatorluğu'na yapacağı yardım 
karşılığında serbest ticaret anlaşması yapılmasını dayatmıştır. Mehmet Ali Paşa'nın tasfiye edilmesi karşılığında Osmanlı İmparatorluğu, İngiltere'nin isteklerine razı olmak zorunda kalmıştır (Adda, 2002: 62). Bu çerçevede Mısır deneyimi, Baltalimanı Ticaret Anlaşması'nın önemli bir altyapısını oluşturmuştur.

Padişah İkinci Mahmut'un başlattığı reformlar da başta İngiltere olmak üzere hem Avrupa ülkelerini hem de Rusya'yı rahatsız etmektedir. Reformların devam etmesi, Osmanlı İmparatorluğu üzerinde emperyalist hevesleri olan ülkelerin çıkarlarıyla ters düşmektedir. $\mathrm{Bu}$ nedenle Osmanlı üzerinde hem iktisadi hem de siyasi baskılar artmıştır (Dura ve Altıparmak, 2000: 20). Osmanlı'nın modernleşme çabaları karşısında artan bu baskılar da Baltalimanı Ticaret Anlaşması'nın zeminini hazırlayan faktörler arasında yer almaktadır.

Siyasi etkenler arasında sayılabilecek diğer bir unsurun ise Osmanlı yöneticilerinin serbest ticaret anlaşmasının sonuçlarını öngörememesi olarak değerlendirilmektedir (Yerasimos, 1977: 628). Sadrazam Reşit Mehmet Paşa, ticaret anlaşması sayesinde iktisadi açıdan çok güçlü olan İngiltere'nin desteğiyle Osmanlı sanayisinin güçleneceğine inanmaktadır. Osmanlı yöneticileri, İngiltere tarafından serbest liberal anlayışın İngiltere'yi kalkındırdığı gibi Osmanlı ekonomisini de güçlendireceğine inanmışlardır. Ancak Pamuk (1994), bu konuda farklı bir görüş ileri sürmekte ve Osmanlı yöneticilerinin anlaşmanın sonuçlarından haberdar olduğunu ifade etmektedir. Bu konu, sonraki bölümlerde tartışılacaktır. Avrupa'da eğitim almış ve liberal ekonomi felsefesiyle yoğurulmuş bir aydın kesim tarafından serbest ticaret anlaşmasının desteklenmesi, Baltalimanı Ticaret Anlaşması'nın ideolojik zeminini hazırlamıştır. Sadrazam Reşit Paşa'nın anlaşmayı bu aydın grubunun lideri olarak imzaladığı ifade edilmektedir (Dura ve Altıparmak, 2000: 20).

\section{BALTALIMMANI TICARET ANLAŞMASI'NIN İÇERİĞİ}

Anlaşma imzalanmadan önce de özellikle kapitülasyonlar nedeniyle İngiltere'nin imtiyazları söz konusudur. Dış ticaret alanında Osmanlı İmparatorluğu ithalattan \%3 gibi çok düşük bir gümrük vergisi tahsil etmektedir. Sadece savaş dönemlerinde Osmanlı'nın dış ticarete olağanüstü vergiler koyma hakkı saklı tutulmuştur. Ancak Osmanlı Devleti, darlık zamanlarında bazı hammadde ve gida maddelerine ihracat yasağı getirebilmektedir. Bu durum başta İn- giltere olmak üzere Avrupa ülkeleri açısından belirsizlik ifade etmektedir. İngiltere'nin rahatsız olduğu diğer bir uygulama ise yed-i vahit, yani tekel sistemidir. Yed-i vahit sistemine göre iç ticaret Osmanlı tebaasının tekelindedir. Yabancılar iç piyasaya girip rekabet sürecine girememektedir. Ayrıca birçok malın ithalatı ve ihracatı tekellerin eline verilmiştir. Üretici ve ithalatçıların mallarını bu tekellere satma zorunluluğu bulunmaktadır. Bunun dışında imparatorluk içinde malların kentler arasındaki hareketi izne tabi olduğundan Avrupa devletleri açısından bu durum bürokratik sorun olarak görülmektedir. İç ticarette alınan vergilerin yüksekliği de İngiltere için önemli bir gelir kaybı olarak değerlendirilmektedir (Avcıŏlu, 1969: 71).

Osmanlı İmparatorluğu'nun Rus ve Fransız yayılmacılığının etkisinden çıkarak İngiltere ekseninde kalmasını sağlamak ve İngiltere tüccarlarının Osmanlı topraklarında kolaylikla ticaret yapabilmesinin altyapısını oluşturmak amaçlarını güden Baltalimanı Ticaret Anlaşması, 16 Ağustos 1838 tarihinde Mustafa Reşit Paşa ile İngiltere büyükelçisi Ponsonby arasında imzalanmıştır. Anlaşma, 8 ana madde ve 3 ek maddeden oluşmaktadır (Eşiyok, 2010: 81). Öncelikle yed-i vahit uygulamasından vazgeçilmiştir. Mal alımı ve nakliyesi için de tezkere istenmeyecektir. Ayrıca yed-i vahit uygulamasına son verilmesiyle ihraç yasakları da son bulmuş, böylece İngiltere istediği malları yurtdışına çıkarabilme olanağına kavuşmuştur. Sanayi mallarında \%12'ye kadar çıkan gümrük vergileri \%3'e indirilmiştir. İhraç mallarından iskelede alınacak vergi ise $\% 9$ seviyesinde tutulmuştur. Bir başka ifadeyle $\% 3$ gümrük vergisiyle birlikte ihracattan toplam \%12 vergi alınması karara bağlanmıştır. İç ticarette İngiliz tüccarları, en ayrıcalıklı yerli tüccardan daha fazla vergi ödemeyecektir. Böylelikle İngiliz tüccarların en imtiyazlı yerli tüccar sıfatı kazanması sağlanmıştır. Daha önceden kapitülasyonlar aracılığıyla verilen imtiyazların da aynen korunması sağlanmıştır. Verilecek yeni imtiyazlar eskilerinin üzerine eklenecektir. Bu madde ile kapitülasyonlar ile daha önce elde edilen haklar garanti edilmiştir. Verilen imtiyazlardan sadece İngiliz tüccarlar değil, İngilizlerin ortak olduğu diğer devletlere mensup şirket ve tüccarlar da yararlanacaktır. Bu madde ile İngiltere tüccarlarıyla ortak olmak, bir ayrıcalık haline getirilmiş ve böylece İngiltere şirketleri daha değerli hale gelmiştir. Anlaşma ile İngiltere'ye verilen diğer bir ayrıcalık, boğazlardan geçiş hakkı ile ilgilidir. İngiltere deniz tüccarının mal- 
larının Akdeniz ve Karadeniz boğazlarından geçişi serbest hale getirilmiştir. Osmanlı İmparatorluğu limanlarında malların gemiden gemiye aktarılması da serbest olacak ve bu işlemler için ayrıca vergi alınmayacaktır. Baltalimanı Ticaret Anlaşması'nın İngiliz tüccarlarına sağladığı diğer bir önemli imtiyaz ise Osmanlı toprakları içinde serbest dolaşım hakkının getirilmiş olmasıdır. Bu imtiyaz ile İngiliz tüccarları tıpkı Osmanlı vatandaşları gibi bir şehirden diğerine mallarını serbestçe götürebilecek ve bu işlem için Osmanlı Devleti herhangi bir vergi tahsil etmeyecektir. Osmanlı tüccarları ise kentler arasındaki mal dolaşımı için vergi ödemeye devam edecektir. Bu madde ile Osmanlı tüccarı aleyhine haksız rekabet ortaya çıkmıştır (Memiş, 2008: 90). Ayrıca İngiliz tüccarlarına Osman11 toprakları içerisinde şirket kurma izni de verilmiştir. Bunlara ek olarak anlaşma öncesinde Osmanlı İmparatorluğu tarafından diğer devletlere verilen ayrıcalıkların İngiltere için de geçerli olması ayrı bir madde ile hükme bağlanmıştır. İmzalanan ticaret anlaşması belirli bir süreyi kapsamamakta sürekli olarak geçerli olacağı ifade edilmektedir. İçeriği özetle bu maddelerden oluşan Baltalimanı Ticaret Anlaşması ile İngiltere, kapitülasyonlar ile ulaşamadığı ve hedeflediği tüm imtiyazlara sahip hale gelmiştir (Akşin, 2000: 25). Anlaşmanın imzalanması ile Osmanlı İmparatorluğu'nun Avrupa liberalizmi ile bütünleşmesinin tüm koşulları sağlanmış olmuştur. Siyasal liberalizm süreci ise bir yıl sonra, 1839 yılında Tanzimat Fermanı ile başlayacaktır. Siyasal liberalizm uygulamalarının da İngiltere'nin baskısıyla gerçekleştirildiği bilinmektedir (Köymen, 2007: 87). Baltalimanı Ticaret Anlaşması, Osmanlı İmparatorluğu'nun kapitalizm ile eklemlenmesinin temelini oluşturmuş ve bu çerçevede 1839 yılında Fransa ile ve ilerleyen yıllarda ise diğer Avrupa devletleriyle benzer koşulları içeren ticaret anlaşmaları yapılmıştır (Baskıcı, 2005: 49).

\section{ANLAŞMANIN OSMANLI IMMALAT SANAYIII ÜZERİNDEKİ ETKİLERİ}

Merkantilizm ile başlayıp sanayi devrimiyle devam eden süreç içinde Osmanlı İmparatorluğu ile Avrupa arasındaki teknolojik farkların ortaya çıkması 18 Yüzyılın ikinci yarısından sonra belirginleşmiştir. Savaş alanlarında Osmanlı topçularının başarısızlığı savaşların kaybedilme nedeni olarak ortaya çıkınca Osmanlı, batı teknolojisini taklit etmeye başlamıştır. $\mathrm{Bu}$ kopyacı anlayış kısa süre içinde bütün üretim sektörlerine, hatta tüketim biçimlerine yayılmıştır.
Batılılaşmanın bu şekilde anlaşılması ve kabul görmesi, imalat sanayii üzerinde olumsuz etkiler yaratmaya başlamıştır. Osmanlı'da üretimde gedik adı verilen ve sektörleri korumayı amaçlayan bir sistem uygulanmaktadır. Gedik sistemi sayesinde sektöre girişler denetlenmekte, ancak belli şartlar sağlandıktan sonra işyeri açılmasına izin verilmektedir. Örneğin bir kimse çırak ve kalfalıktan yetişip gerekli olduğu için açılan ustalık makamına geçmedikçe, bir başka ifadeyle gedik sahibi olmadıkça bir işyeri açıp faaliyette bulunamamaktadır. Böylece ilgili imalat sektörü korunmakta ve ayakta durması sağlanabilmektedir. Ayrıca gediklerin yapacağı üretimin miktarı da ihtiyaca göre saptanmakta ve daha fazla üretim yapılmasına izin verilmemektedir (Bayram 2014: 59).

Gedik sistemi, 18. Yüzyılın sonuna kadar işlevini kaybetmemiş, üretim ve ticareti koruyan yapısını sürdürmüştür. Ancak Baltalimanı Ticaret Anlaşması'nın imzalanmasının ardından İngiliz mallarıyla birlikte tüccarlarının da Osmanlı kentlerine akın etmesiyle birlikte gedikler de eski fonksiyonlarını yitirmişlerdir. Örneğin İngiltere'den ucuz ve bol miktarda tuhafiye ve manifatura eşyası gelmeye başlayınca Kapalıçarşı'daki tülbent ve kıl kumaş gedikleri gedik haklarını yüksek bedellerle satarak çarşının arka sokaklarına sığınmışlardır. Bu tülbent ve kıl kumaş esnafi, Marmara havzasında yoğunlaşmış binlerce tezgah tarafından beslendiklerinden, çarşıdaki işlerinin bozulması, kısa zamanda bu tezgah sahiplerinin ortadan kalkmasına neden olmuştur (Kazgan, 1982: 80). Ayrıca İngiltere'nin anlaşma ile elde ettiği rekabet avantajı nedeniyle Osmanlı piyasasında İngiliz mallarının fiyatları ucuzlamıs, bu durum halkın da İngiliz mallarına yönelmesine neden olmuştur (Önsoy, 1988: 19). Anlaşmanın sağladığı imtiyazlar ile birlikte İngiltere'den yapılan pamuklu mensucat ithalatı artarak Osmanlı iplik üretimine ve dokumacılık sektörüne büyük zarar vermiştir (Pamuk, 1983: 88).

Osmanlı'nın yerli üretici ve zanaatkarları, alışık oldukları gedik sistemi sarsılmaya başlayınca bunalıma girmiş, bir kısmı Avrupa fabrikalarında üretilmeyen bazı dini ve ufak tüketim eşyalarının üretimine yönelmişlerdir. Süpürge, nalın, kilim, çeşitli başlık ve örtüler gibi sadece Türk ve Müslümanlar tarafından kullanılan ürünlerin üretimine geçen bu işletmeler, ticarete yönelmekte zorluklar yaşamışlardır. Bunun en önemli nedeni kapitalist üretim ve ticaret ilişkilerinin kavranmasında yaşanan güçsüzlüklerdir. Azınlıklar 
kendi aralarında ticari işbirlikleri kurarak ticaretlerini büyütürken Türk ve Müslümanların piyasanın dış1na atılmıştır. 1839 Tanzimat Fermanı ile önemli haklara kavuşan azınlıklar, bu haklarını ticari alanda da kullanarak büyük ilerlemeler kaydetmiştir. 1839'dan sonra idari kadronun Türk ve Müslüman kadrodan oluşturulma çabaları da üretim işlerini kaybeden halkı devlette çalışmaya yönlendirmiş ve ekonomik hayattan çekilme sürecini hızlandırmıştır. Bu gelişmelerle birlikte yerli üretim çökmüştür. Örneğin İstanbul'da 1830 yılında dokuma tezgahı sayısı 3160 iken 1866 y1lında 37'ye düşmüştür (Göçek, 1999: 97). İthal mallar böylece bütün Osmanlı pazarını ele geçirmiştir. Anlaşmanın sonucunda diş ticaret hacmi 12-15 kat artarken Avrupa kaynaklı tekstil ithalat1 100 kat artmıştır (Dura ve Altıparmak, 2000: 23). Sonuç olarak anlaşmadan itibaren 1920 yılına kadar Osmanlı İmparatorluğu'ndaki küçük ve orta ölçekli sanayi işletmeleri; yok olma, yeniden kurulma, teknoloji değişmeleri, kapitalizmin etki alanına girmiştir. Diğer bir yandan imparatorluğun iç ve dış siyaseti, azınlıkların siyasi ve iktisadi amaçları gibi konular da Osmanlı sanayiini etkilemiştir.

Osmanlı üretim sektörleri bu şekilde çökerken devlet yönetimi bu gerilemeyi önlemek ve sanayiyi tekrar canlandırmak için fazla bir çaba göstermemiştir. Halbuki Almanya, Avusturya-Macaristan, Rusya gibi ülkeler gecikmeli de olsa sanayi devrimi sürecine girmiş ve kısa sürede İngiltere ile rekabet edecek güce ulaşabilmişlerdir. Osmanlı'nın sürece girememesinin çeşitli nedenleri bulunmaktadır. Öncelikle sanayi ülkelerinde işçi örgütlerinin kurulması ve işçi hakları nedeniyle ücretler yükselmiş, bu durum ürün fiyat artışlarına sebep olmuştur. Bu nedenle sanayi ülkeleri Avrupa dışındaki pazarlara açlarak fiyatların yükselmesini önlemişlerdir. Devletler tarafından desteklenen sanayi ürünleriyle Osmanlı pazarına çıkan işletmelerin birbirleriyle rekabeti sonucunda Osmanlı'da fiyatlar sürekli düşmeye başlamıştır. Sürekli düşen fiyatlar nedeniyle Osmanlı üretimi bu ekonomik yapı içerisinde ayakta kalma olanağını yitirmiştir. Osmanlı Devleti bu konuda hem kapitülasyonlar nedeniyle hem de Baltalimanı Ticaret Anlaşması maddeleri gereğince gümrük politikaları uygulayamamış, dolayısıyla yerli sanayisini koruyamamıştır (Eşiyok, 2014: 91). Bir başka ifadeyle Osmanlı Sanayiinin yeniden toparlanmasının önü de bu anlaşma ile tıkanmaktadır. Ayrıca yine anlaşma nedeniyle Osmanlı tüccarlarının yabancı tüccarlara göre daha ağır vergi yükünün bulunması da sanayinin yeniden organize olmasında önemli bir engel teşkil etmektedir (Tezel, 1994: 73).

Üretim sektörlerinin anlaşmadan olumsuz etkilenmesi ve devletin gümrük politikası araçlarından yoksun bırakılması nedeniyle yerli üretimin rekabete karşı savunmasız kalmasının o dönemdeki Osmanlı Devlet yönetiminin bakış açısı çerçevesinde incelenmesi de önem arz etmektedir. Osmanlı yönetimi gümrük vergilerini önemli bir gelir kapısı olarak değerlendirmektedir. Gümrük vergisi yükseltilirse iç talepte daralma meydana geleceğinden gümrük vergi gelirlerinin azalacağından endişe edilmektedir. Üstelik bu vergiler yabancı altın paralar ile tahsil edildiğinden Osmanlı yönetimi için daha değerli görülmektedir. Yerli üretimin azalması, devlet için büyük bir gelir kaybını ifade etmemektedir, çünkü gedik sistemi içinde bulunan yerli işletmeler fazla kar etmedikleri için bunların ödeyeceği vergiler, ithalattan alınan gümrük vergilerine karşı bir alternatif teşkil etmemektedir. Ayrıca konuya vergi gelirleri açısından bakan Osmanlı yönetimi, yeni açılan mağaza, dükkan, depo gibi yerler nedeniyle rantı yükselen arsa ve gayrimenkuller üzerinden alacağı vergilerin yükselmesiyle gelirlerini arttırmayı amaçlamaktadır. İstanbul, İzmir, Trabzon, Selanik gibi kentlerde batı mallarının tüketiminin yaygınlaşması ile açılan yeni işyerleri ve bunlara bağlı olarak kentleşme hızının artması sonucu konut yapımının hızlanması, eğlence yerlerinin açılması, at arabası sayısının artması hükümet bakımından kolayca vergilendirilebilen gelirlerin doğmasına sebep olmuştur. Devletin bu tutumu nedeniyle bütün teşebbüs gücü pazarlama ve dağıtım faaliyetlerine yönelmiş ve sanayi girişimi gerektiren dürtü zay1flamıştır (Kazgan, 1982: 88). Bir başka ifadeyle, bir yandan sanayi devrimi ve Baltalimanı Ticaret Anlaşması nedeniyle sekteye uğrayan yerli üretim, diğer yandan da devletin iktisat politikaları nedeniyle daha da zayıflamış, hatta yok olmuştur. Nitekim Abdülaziz dönemine gelindiğinde el tezgahları üretim hattından neredeyse tamamen çekilmiştir (Çadırcı, 1997: 350). $\mathrm{Bu}$ olumsuz etkiler zaman içinde Balkanlar, Suriye ve Mısır gibi uzak Osmanlı coğrafyasında da hissedilmiş, dokumacıllk sektörü bu bölgelerde bitmiştir (Karpat, 2002: 89). Osmanlı Devleti'nin kısa vadedeki sağlam vergi gelirlerini gözeterek yerli üretimin yok oluşuna göz yumması, uzun vadede devlete de zarar vermiş ve Osmanlı İmparatorluğu tamamıyla bir açık pazara dönüşmüştür. Böylece iktisadi bağımsızlık 
ortadan kalkmıştır. Bu süreçte alınan dış krediler de üretimin arttırılması çabalarında değil, dış açıkların kapatılmasında kullanılmıştır. Bu dönemde Kırım Savaşı'nın da başlamasıyla finansman ihtiyacı artmış, 1854 yılında ilk defa dış borç alınmış ve bu tarihten sonra sürekli borçlanmalarla devlet bir borç batağ1na sürüklenmiştir. Bu süreç, 1881 yılında Muharrem Kararnamesi ile Düyun-u Umumiye teşkilatının kurulmasıyla sonuçlanacak ve Osmanlı Devleti vergi gelirlerini borçlu olduğu devletlere borçlarına karşıllk olarak temlik edecektir (Çavdar, 1970: 41).

\section{ANLAŞMANIN OSMANLI'YA FİNANS KAPITTAL AÇISINDAN ETKÍLERİ}

Baltalimanı Ticaret Anlaşması sonucunda ithalattan alınan gümrük vergilerinin $\% 12$ den $\% 3$ seviyesine düşmesiyle yabancı ülke malları Osmanlı pazarını istila etmiş, ancak bu durum Osmanlı vergi gelirlerini olumlu etkilemiştir. Orantısız artan ithalat nedeniyle gümrük vergileri yüzdesel oran olarak düşse de toplam gelir bakımından artış göstermiştir. Yerli üretimden vergi almada devlet zaten başarısız olduğundan Osmanlı sanayisinin çökmesi devlet açısından büyük bir vergi kaybını ifade etmemektedir. Ancak yerli üretimin çökmesiyle birlikte ihracat çok azalmış ve böylece Osmanlı İmparatorluğu ekonomisi dışarıdan beslenen bir yapıya bürünmüştür. Bu yapı nedeniyle 1850'den itibaren Osmanlı ekonomisi ithalatını finanse edemez hale gelmiştir. Ayrıca 1839 Tanzimat Fermanı'ndan itibaren memur sayıs artmıs, buna bağlı olarak ek finansman ihtiyacı ortaya çıkmıştır. Tarımsal üretimin istenen seviye ve kaliteye çıkarılamaması sebebiyle tarım gelirlerinin de ithalatı finanse etme olanağı bulunmamaktadır. Ayrıca artan finansman ihtiyacı nedeniyle mültezim sistemi de bozulmuş ve tarımdan elde edilen vergiler aşınmaya başlamıştır. Tüm bu gelişmeler, Osmanlı İmparatorluğu'nu Avrupa Finans Kapitali'ne mecbur bırakmıştır. 1854 yılına gelindiğinde Kırım Savaşı'nın da getirdiği yükle artık dış borçlanma kaçınılmaz olmuştur. Dış borcun alınmasıyla tüketim piyasası iyice canlanmıştır. Osmanlı ekonomisi, artık sürekli olarak borç almadan varlığını sürdüremeyecek bir yapıya bürünmüştür. Alınan borçlar ile her seferinde yeni yatırımlar yapılacağı söylenmiş fakat bütün para yine ithalat ve tüketime gitmiştir. Dolayısıyla batı ülkelerinden alınan borç paralar yine bu devletlere geri gitmiştir. Böylece hem batı ülkelerindeki şirketlerin talep yetersizliği sorunu ortadan kalkmış hem de egemen devletler faiz gelirlerini arttırarak daha zengin hale gelmiştir. Vadesi gelen borçları ve faizleri ödemek için tekrar borç para bulmak zorunda kalan Osman1 maliyesi artık çökmüştür. Finans kapital için artık Osmanlı İmparatorluğu hasta adam olarak tanımlanmaktadır. Dış borçların ödenmesinin olanaksızlığı, devletin gelirlerinin finans kapitale temlik edilmesine kadar gitmiş, bu amaçla finans kapitalin yönetiminde Düyunu Umumiye kurulmuştur. Osmanlı İmparatorluğu, böylece ekonomik olarak tüm bağımsızlığını kaybetmiş ve iflasını açıklamıştır. Ayrıca bu dönemde diş borçların komisyonculuğunu yapacak bir nesil de yetişmiştir. Böylece finans kapitalin beslediği sermaye piyasaları ve borsalarda Galata sarrafları kendilerini göstermeye başlamıştır (Kazgan, 2005: 15).

Osmanlı İmparatorluğu karşısında finans kapitalin diğer bir özelliği de demiryolları, birkaç maden işletmesi ve tütün tekeli dışında üretime ve iktisadi faaliyetlere dönük sermaye ve girişim olarak eksikliğidir. Gerçekten diğer ülkelere sabit sermaye yatırımı yapmak için giden finans kapital, Osmanlı'ya bu amaçla gelmemiştir. Bu nedenle Osmanlı kaynakları atıl kalmıştır. Bu duruma neden olarak Osmanlı İmparatorluğu'nun hukuk sistemi gösterilmektedir. Bu nedenle Osmanlı yönetimi bu konuda çalışmalar yapmış, hukuk sistemini revize etmek için girişimlerde bulunmuştur, fakat bu alanda başarılı olamamıştır. Bunun üzerine finans kapitalin siyasi stratejisi değişmiş ve Balkan devletlerinin ortaya çıkması ve güçlenmesi için çalışmaya başlamıştır. Gerçekten de 1850'lerden sonra finans kapital; Yunanistan, Sirbistan, Romanya ve Bulgaristan'a yatırımcı ve işletmeci olarak akmaya başlamış ve bu ülkelerin Osmanlı İmparatorluğu'ndan toprak talepleri devamlı olarak finans kapital kurumları tarafından desteklenmiştir (Kazgan, 1982: 107).

\section{SONUÇ}

Avrupa ülkelerinde merkantilizm ile başlayarak sanayi devrimi ile devam eden süreç, sadece iktisadi ve teknik gelişmeyi değil, aynı zamanda bir küreselleşmeyi de ifade etmektedir. Merkantilizm döneminde özellikle dış ticaret yoluyla büyük bir sermaye birikimine ulaşan Avrupa ülkeleri, İngiltere'nin başını çektiği sanayi devrimiyle önemli teknolojik ilerlemeler kaydetmiş ve üretimlerini büyük ölçüde arttırmışlardır. Gerek artan üretimi pazarlama sorunu gerekse üretimin sürekliliğini sağlayacak hammadde ihtiyacı İngiltere'yi Avrupa dişındaki pazarlara 
yöneltmiştir. Bu bağlamda İngiltere, Latin Amerika'dan Çin'e kadar pek çok pazarı değerlendirmiş ve emperyalist bir güç kazanmıştır. İngiltere emperyalizminin Osmanlı İmparatorluğu'ndaki yansıması ise Baltalimanı Ticaret Anlaşması olarak gerçekleşmiştir. Merkantilizm döneminde özellikle kapitülasyonlar yoluyla Avrupa ülkelerine verilen imtiyazlar sonucunda sermayesi tükenen Osmanlı ekonomisi, sanayi devrimine hazırlıksız yakalanmıştır. Sanayi devrimi sürecinde açık pazara dönüşen Osmanlı ekonomisi, bu duruma rağmen 1800'lü yılların başına kadar gücünü koruyabilmiş ve ihracat yapabilen yapısını sürdürebilmiştir. Özellikle yed-i vahit uygulaması, gedik sistemi, ihracat yasakları gibi politikalar sayesinde bu yıllarda bir şekilde üretim devam etmektedir. Bu uygulamaların ortadan kaldırılması ve Osmanlı yerli üretiminin çökmesi Baltalimanı Ticaret Anlaşması sonrasında gerçekleşmiştir. Anlaşmayla ithalattan alınan gümrük vergilerinin düşürülmesi, İngiltere tüccarına sağlanan vergi imtiyazları, yabancı malların Osmanlı kentleri arasında serbestçe dolaşımı, boğaz geçiş hakları gibi uygulamalar, yerli üretimi olumsuz etkilemiş ve imalat sektörleri çökmüştür.

Osmanlı Devleti, ilk aşamada anlaşmadan olumlu etkilenmiştir. Yerli üretimin düşük karları ve Osmanlı'nın vergi toplama konusundaki başarısızlığı nedeniyle düşmüş olan vergi gelirleri, ithalatın artmasıyla gümrük vergileri çerçevesinde yükselmiştir. Ayrıca yeni açılan mağazalar ve artan gayrimenkul rantları sayesinde devlet yeni vergilendirilebilir kaynaklara kavuşmuştur. Bu açıdan bakıldığında Osmanlı yönetiminin anlaşma sonucunda yerli üretimin çökeceğini öngördüğü söylenebilir. Yani Osmanlı İmparatorluğu'nun esasen anlaşmanın sonuçlarından haberdar olduğu ve bunu isteyerek imzaladığı bu çalışmanın önemli bir çıktısını oluşturmaktadır. Osmanlı'nın bu öngörüsü ilk yıllarda gerçekleşmiş, artan ithalat ile birlikte vergi gelirlerinde büyük artışlar görülmüştür. Ancak yerli üretimin çökmesiyle ihracat gelirleri azalmış ve uluslararası rekabet nedeniyle Osmanlı'nın ihraç ettiği hammadde ve bazı gıda ürünlerinin fiyatları düşmüştür. Bu durumda ithalat finanse edilemez hale gelmiş ve düşmeye başlamıştır. İthalatın azalmasıyla birlikte devletin vergi gelirleri de düşmüştür. 1839 Tanzimat Fermanı sonucunda artan memur sayısı da devletin finansman ihtiyacını arttırmış ve ilk defa Osmanlı İmparatorluğu dış borç almak zorunda kalmıştır. Bu tarihten itibaren devlet borç sarmalına girmiș ve finans kapitalin kucağına düşmüștür. İkti- sadi bağımsızlığını kaybeden Osmanlı İmparatorluğu, ilerleyen süreçte batılı devletlerin yönetiminde kurulan Düyun-u Umumiye örgütüne gelirlerini borçlarına karşılık temlik etmek zorunda kalmıştır. Ayrıca başka ülkelerde sabit sermaye yatırımlarına girişen Avrupa finans kapitali, Osmanlı İmparatorluğu'nda bu yola girmemiştir. Bunun nedeni olarak Osmanlı hukuk sisteminin uygun olmaması gösterilmektedir. Bu nedenle Avrupa finans kapitali Osmanlı'dan ayrılmak isteyen ülkelerin bağımsızlık ve toprak taleplerine destek vermiş ve bu ülkelere sabit sermaye yatırımları yapmıştır. Bir başka ifadeyle Baltalimanı Ticaret Anlaşması'nın iktisadi sonuçları ile siyasi sonuçları iç içe geçmiştir.

Sanayi devrimiyle başlayan küreselleşme sürecinden Avrupa ülkeleri çok kazançlı çıkarken Osmanlı İmparatorluğu hem siyasi hem ekonomik açıdan çöküş süreci yaşamıştır. Bu yıllarda başlayan küreselleşme politikaları tüm dünyada 1929 ekonomik krizine kadar egemen olmuştur. Ekonomik krizden sonra devletler tekrar korumacı ekonomik politikalara dönmüş ve kamu ağırlıklı ekonomik yapılarla krizi aşmaya çalışmışlardır. Ancak 1980'li yıllardan itibaren tekrar küresel ekonomi anlayışının egemen olduğu görülmektedir. ABD ve İngiltere'nin başını çektiği liberal ve küresel iktisat modeli tüm dünyada yeniden temel anlayış haline gelmiştir. Türkiye de 24 Ocak 1980 kararlarıyla küresel ekonomiyle bütünleşmiş, bu çerçevede önce uluslararası mal hareketlerini, 1989 yılından itibaren ise uluslararası sermaye hareketlerini serbest bırakmıştır. Böylece ekonominin bazı alanlardaki kırılganlığı artmış ve Türkiye ekonomisi bu süreçte 1994 ve 2001 yıllarında iki büyük finansal kriz yaşamıştır. Ayrıca küreselleşme nedeniyle finansal krizlerin bulaşıcılığı artmış ve 2008 yılında ABD'de ortaya çıkan finansal kriz, diğer ülkeleri olduğu gibi Türkiye'yi de etkilemiştir. Bu bağlamda günümüzün küresel ekonomik dünyasında politika yapıcılar açısından tarihte yaşanan Baltalimanı Ticaret Anlaşması ve bu anlaşmanın sonuçları önemli deneyimler içermektedir. Bugün uygulanan küresel ekonomi politikalarının artılarının ve eksilerinin belirlenerek geleceğe yönelik yapılacak iktisat politikalarında bu deneyimlerden faydalanmak Türkiye'nin geleceği açısından önem arz etmektedir. 


\section{KAYNAKÇA}

ACARTÜRK, E ve KILIÇ, R . (2011). Osmanlı Devletinde Kapitülasyonların İktisadi ve Siyasi Perspektiften Analizi, Hacettepe Üniversitesi İktisadi ve İdari Bilimler Fakültesi Dergisi 29(2) , 1-21, Retrieved from https://dergipark.org.tr/en/pub/huniibf/issue/7865/103707

ADDA, J. (2002), Ekonominin Küreselleşmesi (1.Bask1), İletişim Yayınları, İstanbul

AKȘiN, S. (2000). Siyasal Tarih, Osmanlı Devleti (1600-1908), Cilt 3, Cem Yayınevi, İstanbul

AVCIOĞLU, D. (1969). Türkiye'nin Düzeni, Dün, Bugün, Yarın, Bilgi Yayınevi, Ankara

AYDIN, A .(2021). Türkiye Ekonomisinde İhracat ve Gayri Safi Yurt İçi Hasıla Arasındaki Uzun Dönem İlişkisi. Bucak Isşletme Fakültesi Dergisi, 4(1), 30-62. DOI: $10.38057 /$ bifd.865548

AYGÜN, N. (2017). Avrupa Emperyalizminin Aşamaları: Osmanlı Akdeniz'inde Avrupa Ticareti (1700-1830) . Aksaray Üniversitesi Sosyal Bilimler Enstitüsü Dergisi , 1(2) , 3-17. Retrieved from http://aseddergi.aksarav.edu. tr/en/pub/issue/39720/470459

BASKICI, M. M. (2005). 1800-1914 Yıllarında Anadolu'da İktisadi değişim, Turhan Kitabevi, Ankara

BAYRAM, S. (2012). Osmanlı Devleti'nde Ekonomik Hayatın Yerel Unsurları: Ahilik Teșkilatı ve Esnaf Loncaları, İstanbul Üniversitesi İlahiyat Fakültesi Dergisi, Sayfa. 21-40

BERKES, N. (2013). Türkiye İktisat Tarihi, Yapı Kredi Yayınları, İstanbul

CLARK, E.C.(2006), "Osmanl Sanayi Devrimi”, Halil Inalclk, Mehmet Seyitdanlıŏglu (Ed.), Tanzimat Değişim Sürecinde Osmanlı Imparatorluğu, Phoenix, Ankara, 499-512.

ÇADIRCI, M. (1997), Tanzimat Döneminde Anadolu Kent'lerinin Sosyal ve Ekonomik Yapısı (2. Baski), Türk Tarih Kurumu, Ankara.

ÇAVDAR, T. (1970), Osmanlıların Yarı-Sömürge Oluşu (1. Baskl), Ant Yayınları, İstanbul.

DEMIR, R.A. ve KURT, A.S. (2020). "Dıș Ticarette Korumacılık ve Ülkelerin Gelişmişlik Düzeyine Etkileri”. ulakbilge, 47: s. 381-399. doi: 10.7816/ ulakbilge-08-47-01

DURA, C. Ve ALTIPARMAK, A. (2000), 1838 Osmanl - İngiliz Ticaret Anlaşması: Nedenleri ve Sonuçlan, Erciyes Üniversitesi İktisadi ve İdari Bilimler Fakültesi Dergisi, Sayı 16, Sayfa 17-30

EŞIYOK, B. (2014). Osmanlı İmparatorluğu'nun Dünya Ekonomisine Eklemlenmesinde Bir Dönüm Noktası:1838 Serbest Ticaret Anlaşması, Mülkiye Dergisi , 34 (266) , 67-108. Retrieved from https://dergipark.org.tr/en/pub/ mulkiye/issue/267/573

FREEMAN, C. ve SOETE, L. (2003), Yenilik Iktisadı (1.Basım), Ergün Türkcan (Çev.), TÜBİTAK Yayınları, Ankara.

GÖÇEK, F.M. (1999), Burjuvazinin Yükseliși Imparatorluğun Çöküșü Osmanlı Batılılaşması ve Toplumsal Değişme (1. Baskı), Ayraç Yayınevi, Ankara

GÖKBUNAR, A. (2007). Celali Ayaklanmalarının Maliye Tarihi Açısından Değerlendirilmesi. Yönetim ve Ekonomi: Celal Bayar Üniversitesi İktisadi ve İdari Bilimler Fakültesi Dergisi, 14 (1) , 1-24. Retrieved from https://dergipark.org.tr/en/pub/yonveek/issue/13686/165616

GÜNEŞ, Y . (2006). Merkantilizmin Ortaya Çıkıșı . Elektronik Sosyal Bilimler Dergisi, 5 (15) , 1-23. Retrieved from https://dergipark.org.tr/en/pub/ esosder/issue/6129/82200

HAFTER, D. M. (1964) Critics of Mercantilism in France: 1751-1789: The Industrial Reformers. Yayınlanmamış doktora tezi. Yale University, New Haven.

HOBSBAWN, E.J. (1987), Sanayi ve Imparatorluk, Y.Gülerman ve A. Ersoy (Çev.), Dost Yayınları, Ankara.

İNALCIK, H. (2000) İmtiyâzât. İslam Ansiklopedisi içinde (C.22, ss.245252). Türkiye Diyanet Vakfi, İstanbul
JAGIC, S. (2010) Constantinople, 6 avril 1536, Revues plurielles http://www. revuesplurielles.org/ uploads/pdf/12/110/11

KARAKAYALI, H ve DILBER, İ. (2010) Kuramlarda Büyüme ve Kalkınma. Manisa: Emek Matbaacılık ve Yayıncılık, 2010.

KARPAT, H. (2002), Osmanlı Modernleşmesi (1.Baskl), A. Zorlu Durukan, Kaan Durukan (Çev.), İmge Kitabevi, Ankara

KAZGAN, G. (1993). İktisadi Düşünce veya Politik İktisadın Evrimi. İstanbul: Remzi Kitabevi

KAZGAN, H. (1981), Sanayi Tarihi, İTÜ Matbaası, İstanbul

KAZGAN, H. (2005). Osmanli'da Avrupa Finans Kapitali, Roma Yayınları Ekonomi Dizisi, Ankara.

KEYDER, Ç. (2008). Türkiye'de Devlet ve Stnıflar, İletişim Yayınları, İstanbul.

KIRAY, E. (1995). Osmanlı'da Ekonomik Yap ve Dış Borçlar, 2. Baskı, İletişim Yayınları, İstanbul

KÖYMEN, O. (2007). Sermaye Biriktiren Osmanl, Türkiye, Dünya, Yordam Kitap, İstanbul

KÜTÜKOĞLU, M. (1974). Osmanl-İngiliz İktisadi Münasebetleri I (15801838) (1. Bask1), Türk Kültürünü Araştırma Enstitüsü, Ankara

MAILLET, J. (1983). 18. Yüzyıldan Bugüne İktisadi Olayların Evrimi, Çeviren: Ertuğrul Tokdemir, Remzi Kitabevi, İstanbul

MEMIŞ, N. (2008). 19. Yüzyll Osmanlı Imparatorluğu'nda Ekonomik Yapı ve Dış Ticaret, Atatürk Üniversitesi Sosyal Bilimler Enstitüsü İktisat Anabilim Dalı, Yüksek Lisans Tezi s.59-110, Erzurum

ORTAYLI, İ. (1990). “Tanzimat Devri Basını Üzerine Notlar”, Cahit Talas'a Armağan, Mülkiyeliler Birliği Yayınları 9, 397-404.

ÖNSOY, R. (1988), Tanzimat Dönemi Osmanlı Sanayi ve Sanayileşme Politikası (1.Baskl), Türkiye İş Bankası Kültür Yayınları, Ankara.

ÖZVAR, E. (2003). Osmanlı Maliyesinde Malikane Uygulaması, Kitabevi Yayınları, İstanbul

PAMIR, A. (2002). Kapitülasyon Kavramı ve Osmanlı Devleti'ne Etkileri, Ankara Üniversitesi Hukuk Fakültesi Dergisi - dergipark.org.tr 79-120

PAMUK, Ş. (1983). Osmanlı Zanaatlarının Yıkılışı: Pamuklu Tekstil Örneği, 1826-1913, Toplum ve Bilim, 23, 75-99.

PAMUK, Ş. (1994), Osmanlı Ekonomisinde Bağımlllı ve Büyüme 18201913, Tarih Vakfi Yurt Yayınları, İstanbul

PAMUK, Ş. (2009). Osmanlıdan Cumhuriyete Küreselleşme, Iktisat Politikalart ve Büyüme (Seçme Eserleri II) (2 b.). Türkiye İş Bankası Kültür Yayınları, İstanbul

PAMUK, Ş. (2015). Osmanll-Türkiye İktisadî Tarihi 1500-1914. İstanbul: İletișim Yayınları.

ROBERTS, R. D. (2013) Bir Serbest Ticaret ve Korumacılı Öyküsü. Çev. Mustafa Acar. Ankara: Liman Kitapları.

TABAKOĞLU, A. (2016). Osmanl Mali Tarihi, Dergah Yayınları, İstanbul

TEKELİ, İ. ve İLKIN, S. (1999). Osmanlı İmparatorluğu'nda Eğitim ve Bilgi Üretim Sisteminin Oluşumu ve Dönüşümü (2. Bask1), Türk Tarih Kurumu Basımevi, Ankara

TEZEL, Y.S. (1994). Cumhuriyet Döneminin Ikktisadi Tarihi (3.Baskı), Tarih Vakfi Yurt Yayınları, İstanbul

TİMUR, T. (1985). "Osmanlı Devleti, İngiltere ve Rusya; 1838 Ticaret Anlaşmasını Doğru Değerlendirdik mi?”, Yapıt, 10, 4-26

WALLERSTEIN, I. (1979). "The Ottoman Empire and The Capitalist Wor1d-Economy: Some Questions for Research", Fernand Braudel Center Review, 2(3), 389-398.

YALÇIN, E (2015). Şark Meselesi ve Emperyalistlerin Türk Politikası, Toros Üniversitesi IISBF Sosyal Bilimler Dergisi, 2 (4), 0-0, Retrieved from https://dergipark.org.tr/en/pub/iisbf/issue/27277/287162

YARDIMCI, M.E., OFLAZ, E., MENECLER, O. (2020), Tarihsel Süreçte İltizam Sisteminin Sosyoekonomik Etkileri; Devlet Erkinin Kişisel Kullanımı 
“Mültezim”, Düzce İktisat Dergisi, 1(1), 57-68.

YERASIMOS, S. (1977), Azgelişmişlik Sürecinde Türkiye Bizans 'tan Tanzimat'a (3.Bask1), Cilt 1, Gözlem Yayınları, İstanbul.

YILDIRIM, İ. (2001), Ondokuzuncu Yüzyıl Osmanlı Ekonomisi Üzerine Bir Değerlendirme (1838-1918), Firat Üniversitesi Sosyal Bilimler Dergisi Fırat University Jurnal of Social Science Cilt: 11 Sayı: 2, Sayfa: 313-326 